\title{
Pressurized drainage can effectively reduce subsidence of peatlands - lessons from polder Spengen, the Netherlands
}

\author{
Jantine Hoekstra ${ }^{1}$, Annette van Schie ${ }^{1}$, and Henk A. van Hardeveld ${ }^{2}$ \\ ${ }^{1}$ Hoogheemraadschap De Stichtse Rijnlanden, P.O. Box 550, 3990 GJ Houten, the Netherlands \\ ${ }^{2}$ Copernicus Institute of Sustainable Development, Utrecht University, P.O. Box 80.115, \\ 3508 TC Utrecht, the Netherlands
}

Correspondence: Jantine Hoekstra (jantine.hoekstra@hdsr.nl)

Published: 22 April 2020

\begin{abstract}
Reducing soil subsidence caused by peat oxidation is a major challenge in the Dutch peatlands. To maintain suitable conditions for dairy farming water levels are periodically lowered to keep pace with soil subsidence. Consequently, soil subsidence continues, causing increasing water management costs. We experimented with pressurized drainage in Polder Spengen, a peatland polder in the west of the Netherlands that is primarily used for dairy farming. In this polder, surface water levels of $40 \mathrm{~cm}$ below ground surface are maintained, which results in average soil subsidence rates of $7 \mathrm{~mm} \mathrm{yr}^{-1}$. Pressurized drainage is a novel technique to reduce soil subsidence, it uses field drains that are connected to a small water basin. Surface water can be pumped in or out the water basin, which enables active manipulation of the pressure head in the field drains. The objective of this study is to implement this technique into practice and determine its effect on groundwater tables, soil subsidence rates, and water demand. We applied pressurized drainage in 55 ha of peatland meadows in Polder Spengen, distributed over seven farms. We monitored groundwater tables, surface elevation and water demand. Preliminary results show that during the extreme dry summer of 2018, groundwater tables could be maintained at $40 \mathrm{~cm}$ below ground surface, which is $60 \mathrm{~cm}$ higher compared to locations without pressurized drainage. This reduced soil subsidence by $50 \%$. Throughout the entire summer of 2018 , the water demand amounted to $3-$ $5 \mathrm{~mm} \mathrm{~d}^{-1}$. We believe the technique can effectively contribute to minimize soil subsidence, but relatively high implementation costs may be a barrier to large-scale implementation.
\end{abstract}

\section{Introduction}

Soil subsidence is a major problem in peatland areas. In the Netherlands, drainage since the Middle Ages has resulted in a cumulative soil subsidence of 2-4 $\mathrm{m}$ (Schothorst, 1977; Van Asselen et al., 2018). Subsidence in peatlands causes damage to infrastructure and real estate foundations, emission of $\mathrm{CO}_{2}$ and increases management costs for waterways (Van Hardeveld et al., 2018). Therefore, the province of Utrecht and the regional water authority Hoogheemraadschap de Stichtse Rijnlanden (HDSR) aim to reduce the rate of soil subsidence by at least $50 \%$ by the year 2030. To realize this, we started an experiment with the relatively novel technique of pressurized drainage in Polder Spengen. The objective of this pilot study is two-fold:

1. To contribute to our understanding how to put pressurized drainage into practice.

2. To quantify the effects of pressurized drainage on groundwater tables, soil subsidence and water demand.

\section{Study area}

Polder Spengen is a 350 ha large polder situated in the province of Utrecht (Fig. 1). Polder Spengen is an agricultural polder, with a total of 7 active dairy farmers. 


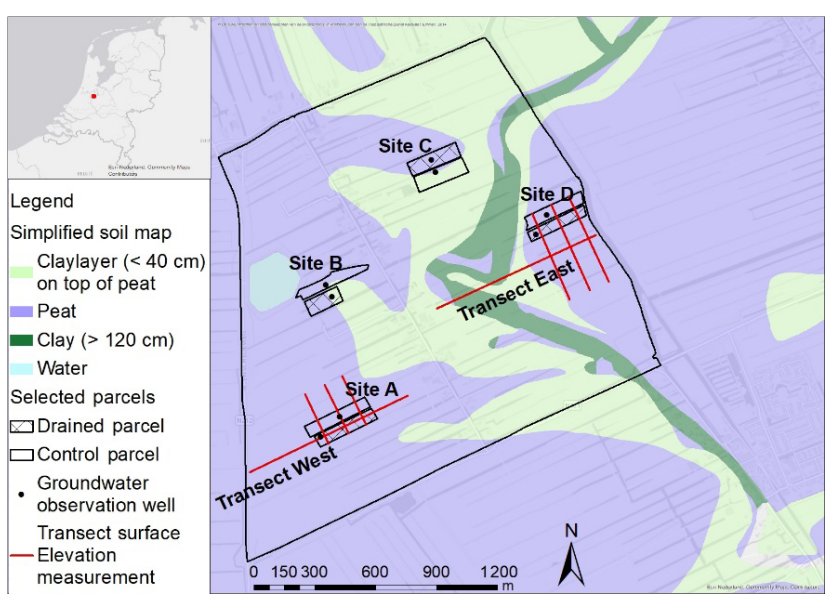

Figure 1. Location of polder Spengen and the four selected sites presented in this article.

During the Holocene period a thick layer of organic material was deposited in the west of the Netherlands (Berendsen and Stouthamer, 2001). In polder Spengen a layer of $7 \mathrm{~m}$ peat still remains. On the east side of the polder a small river has partly cut through the peat layer and deposited locally clay and even sand on top of the peat (Fig. 1). In the Middle Ages (12th century) people converted the natural fens in polder Spengen to agricultural fields and meadows. This resulted in a typical Dutch allotment pattern of elongated, $50 \mathrm{~m}$ wide parcels perpendicular to the main road.

Approximately $10 \%$ of the area of polder Spengen is surface water. The surface water level is controlled by the water authority at a fixed level of NAP $-2.22 \mathrm{~m}$. If needed during dry periods, water can be let in under free fall from a channel on the east side, the difference in elevation head between both water bodies is almost $2 \mathrm{~m}$. Average surface elevation in polder Spengen is NAP $-1.83 \mathrm{~m}$. During winter the groundwater table is almost equal to surface level. During summer, when most peat oxidation occurs, groundwater tables can be $1 \mathrm{~m}$ below surface level. Pressure head difference between the aquifer below the peat layer and the phreatic level in the peat layer is little. Consequently, seepage in the vertical direction is limited.

\section{Method}

$55 \mathrm{Ha}$ of polder Spengen is equipped with field drains, distributed over 24 parcels and 6 farmers. The drain tubes are installed in longitudinal direction of the parcel at a depth of $60 \mathrm{~cm}$ below surface level and an interval of $6 \mathrm{~m}$ with a maximum length of $250 \mathrm{~m}$. At one side the drain tubes are connected at a right angle to a non-porous collector drain, which is at one side connected to a $1.2 \mathrm{~m}$ diameter water basin situated in the water bank (ditch side). The water basin is used to manipulate the pressure head. During dry periods water is pumped from the ditches in to the water basin, increasing the pressure head to stimulate infiltration. During wet periods, water was pumped out of the water basin towards the ditches, creating a negative pressure head and increasing the drainage rate. Both pumps are connected via a programmable logic controller (PLC) to a groundwater observation well, that automatically determines which pump should be active. A target groundwater level is programmed in the PLC. Power for the PLC's was supplied via the grid, except at one location at which a windmill was installed and at another location at which solar panels were used. The area connected to a water reservoir is $2-10$ ha.

Phreatic groundwater tables are measured at all 24 parcels, one observation well per parcel. There are 4 extra parcels without field drains which serve as locations for control measurements. Phreatic groundwater tables are hourly measured. All wells have a phreatic filter at a depth between 1 to $2 \mathrm{~m}$ below ground surface. The wells are installed between two drain tubes in the middle of the parcel and at $2 / 3$ length in longitudinal direction of the drain tube.

Soil subsidence is measured via spirit levelling along 8 transects, with a total length of almost $4 \mathrm{~km}$, encompassing parcels with and without drain tubes. Along these transects every $10 \mathrm{~m}$ the ground surface elevation is measured. This elevation is the median of 20 single elevation measurements within a circle with a diameter of $1 \mathrm{~m}$. This is done to make sure the measurement is not a result of an outlier. The ground surface elevation is measured relative to a fixed point; a bolt in a well-founded farm stable. The measurements or executed early spring, when swell of the peat soil is at a maximum. To get more insight in seasonal ground surface movement, extra measurements are done in summer, fall and winter since August 2018.

The volume of water pumped in and out the water basin is calculated via registration of pump hours, assuming a fixed pump capacity.

\section{Results}

\subsection{Putting pressurized drains into practice}

The participating farmers (mostly the younger ones) wanted a fully automatic system to manage the pressurized drains, to minimize the impact on their farm management. Using a PLC, a reliable and constant power supply is needed. On most locations, we opted for grid power, because parcels not far away from the farm and on the same side of the road as the farm could be relatively easily supplied with grid power, by a power line of up to $1000 \mathrm{~m}$. Two farmers had land far away from their farms. On these locations, the farmers opted for wind energy and solar power. Because these techniques were less reliable, on these locations we used a manual system instead of a fully automatic system. Depending on the system, the total implementation costs amounted to EUR 4700$6500 \mathrm{ha}^{-1}$ (Table 1). The annual costs for maintenance and management are not yet known. 
Table 1. Implementation costs of pressurized drains in polder Spengen. Note that annual costs for maintenance and management are not included.

\begin{tabular}{lr}
\hline System component & Costs (EUR ha ${ }^{-1}$ incl. VAT) \\
\hline Drain tubes + installation at 6 m intervals, and 6 mm diameter & 2500 \\
Automatic operational system (excluding power supply*) & 4000 \\
Manual system using wind energy & 2200 \\
Manual system using solar power & 3500 \\
\hline Total system range & $4700-6500$ \\
\hline * We used a power line that costs EUR $8 \mathrm{~m}^{-1}$. Recalculation to costs ha ${ }^{-1}$ is not possible, this depends on the length of the \\
cable and the area of pressurized drainage now and in the future connected to the cable.
\end{tabular}

\subsection{Quantifying the effects of pressurized drainage}

At four sites with field drains, the groundwater table can be compared with the groundwater table of a control parcel; a similar, adjacent parcel without field drains (Fig. 1). The drain tubes were installed between September 2016 and May 2017. The drain tubes were connected to a water basin (pressurized drainage) in July 2017 (D) and May 2018 (A and C). Site B still is not connected to a water basin.

The results of site A (Fig. 2a) show clearly how (pressurized) field drains work. After installation of the drain tubes, the groundwater table rose $40 \mathrm{~cm}$ in several days. As a result the groundwater table was almost equal to the fixed surface water level of NAP $-2.25 \mathrm{~m}$. This indicates that the system effectively infiltrates water into the soil.

Compared to the control parcel, the groundwater table was $50-60 \mathrm{~cm}$ higher in the summer of 2017 and $10-20 \mathrm{~cm}$ lower in the winter of 2017/2018. The differences during the winter indicate that the drain tubes can also effectively drain water from the soil.

In May 2018 the water basin and pumps where installed (pressurized drainage). Because the cumulative precipitation deficit increased during spring (Fig. 2), we decided to set the groundwater table target level at $30 \mathrm{~cm}$ below ground surface. During summer 2018 we were able to keep the groundwater table equal to the target level. In July 2018, when the weekly evaporation shortage was more than $10 \mathrm{~mm}$, the groundwater table was $80-90 \mathrm{~cm}$ higher compared to the control parcel.

The winter of 2018/2019 was relatively dry, therefore nor drainage nor infiltration did occur. During spring and summer 2019 the weather was much more changeable. Therefore we decided to keep the groundwater target level around $45 \mathrm{~cm}$ below ground surface, to allow for infiltration during dry periods, and preventing peaks in the groundwater table during wet periods.

Measurements at site B (Fig. 2b) reveal the difference between pressurized drainage and field drains directly connected to the surface water. During summers, the impact on the groundwater table is less compared to site A. Especially during the dry summer of 2018, when the groundwater table was up to $50 \mathrm{~cm}$ lower. Note that during the spring and summer of 2019, differences with the control parcel are minimal.
Measurements at site C (Fig. 2c) show almost no difference compared to the control panel. This can be partly explained by regular sprinkler irrigation from above. After installation of the drain tubes we noted that this farmer irrigates on a regular bases during summer, both on the drained and the control parcel.

Measurements at site D (Fig. 2d) show a distinguished difference against the control parcel, although smaller compared to site A. During the summer of 2018, the maximum difference was $50 \mathrm{~cm}$, instead of $80-90 \mathrm{~cm}$. The smaller difference can be attributed to flooding of the control parcel in July 2018 , which caused a $30-40 \mathrm{~cm}$ rise in the groundwater table, or the clay deposits on top of the peat soil.

\subsection{Seasonal patterns of uplift and subsidence}

From spring 2017 to the summer of 2019 , the surface elevation is measured 6 times along the transects (Fig. 3). The first measurement was done early spring 2017, the second measurement approximately 1 year later. On the west side of the research area, net displacement was minimal, whereas on the east side, a net uplift of $1-2 \mathrm{~cm}$ had occurred, most likely caused by swelling during the relatively wet winter of 2017/2018.

During summer 2018 an extra measurement was done to get more insight the seasonal fluctuation in movement of the ground surface. Ground surface levels of the control parcels lowered between 7.5 and $9.5 \mathrm{~cm}$. Ground surface level of drained parcels lowered between 3.5 and $5 \mathrm{~cm}$. Note that summer 2018 had the highest precipitation deficit since 1976. The measurement at the end of the winter 2019 shows a ground surface level rise of all parcels; control on average $6 \mathrm{~cm}$ and drained on average $2.5 \mathrm{~cm}$. The measurement in early spring 2019 shows a difference between east and west. All parcels on the east side of the polder continued to rise at the same rate, whereas the rising rate of parcels on the west began to decelerate. The measurements in the summer of 2019 showed similar patterns of subsidence as the previous year, although with somewhat smaller magnitudes. A comparison of the measurements in the early spring of 2018 and 2019 show that over this one year period, a net subsidence 


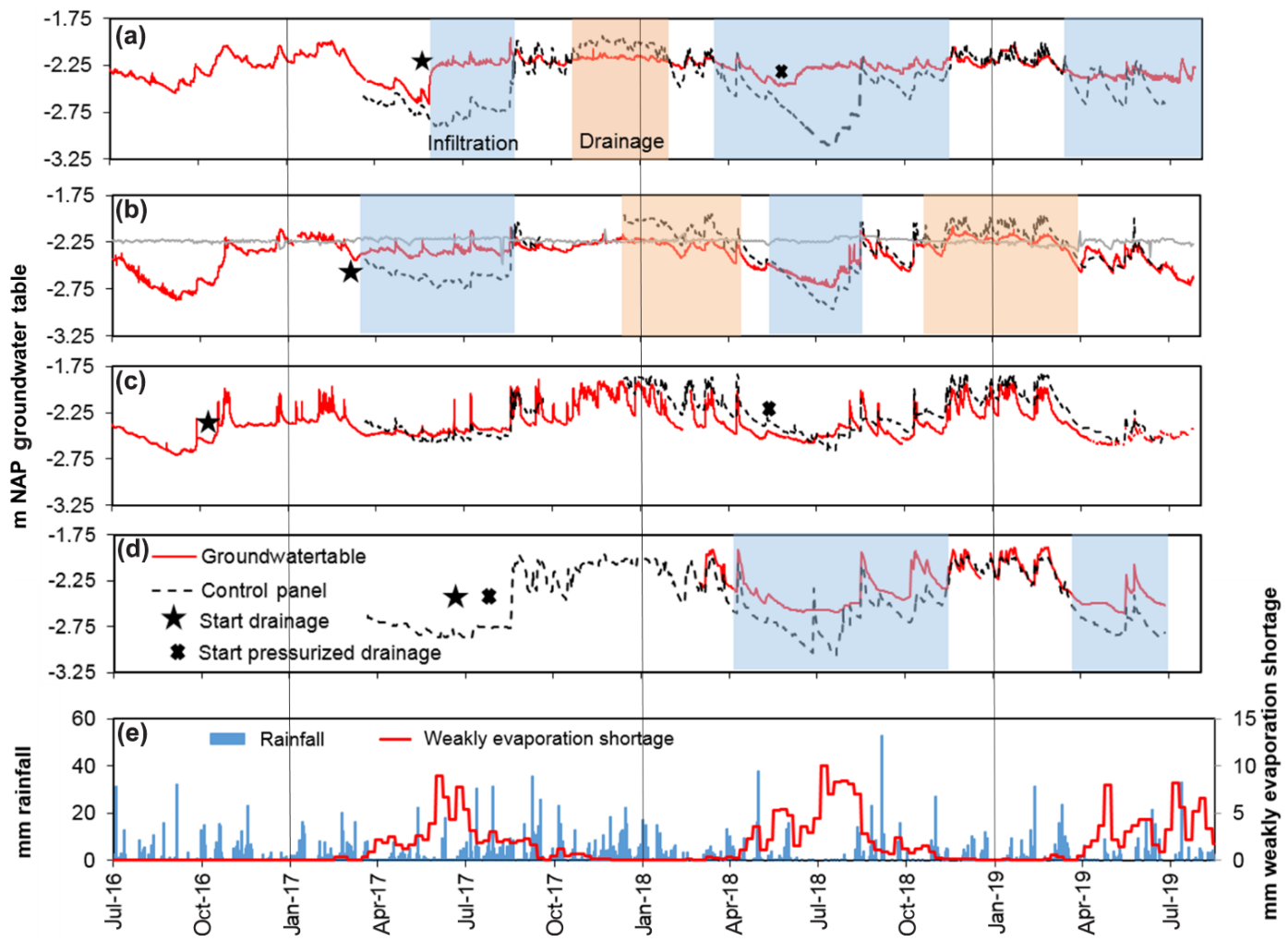

Figure 2. Groundwater tables on four sites (Fig. 1) and meteorological conditions in the period 2017-2019.

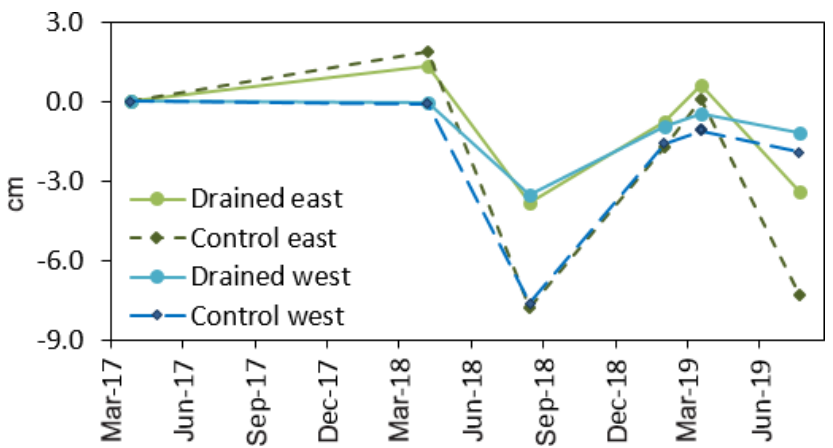

Figure 3. Ground Surface Level measurements along 4 transects (Fig. 1), since spring 2017 of drained and non-drained parcels.

occurred of $0.4-1.8 \mathrm{~cm}$. At both sides of the research area, the control parcels subsided more than the drained parcels, with a difference of $1 \mathrm{~cm}$ on the east side and $0.6 \mathrm{~cm}$ on the west side of the research area. Noteworthy, the control parcel at the east side of the polder subsided almost $1 \mathrm{~cm}$ more than the west side.

\subsection{Water demand during the summer of 2018}

During the summer of 2018, the maximum volume of water pumped into the water reservoirs at site $\mathrm{D}$ was almost $6 \mathrm{~mm} \mathrm{~d}^{-1}$, whereas at site $A$ the water demand was $3 \mathrm{~mm} \mathrm{~d}^{-1}$

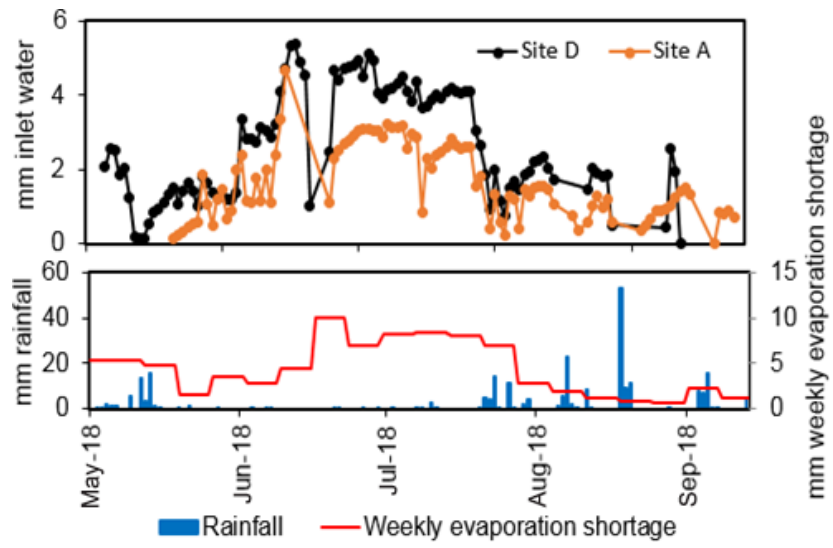

Figure 4. The water demand (sites A and D, Fig. 1), the rainfall, and the weekly cumulative precipitation deficit during the summer of 2018. Note that this period had the highest precipitation deficit since 1976.

(Fig. 4). The water demand at site A almost equals the amount of evaporation, whereas the water demand at site $\mathrm{D}$ is much higher. We believe the difference between both sites is most likely caused by a leakage flux within the parcel at site $\mathrm{D}$, we observed some very soggy soil spots combined with a different type of vegetation that could not be explained by any other phenomenon. 


\section{Discussion}

\subsection{Handling implementation barriers}

Putting pressurized drainage into practice as we did in polder Spengen is probably too costly for farmers. Although the participating farmers were quite enthusiastic about the technique, observing a range of practical advantages for their farm management, the agricultural benefits do not merit an investment of EUR 4700-6500. However, we believe that if this technique is further refined and applied on a large scale, costs will decrease significantly, which will help to overcome the financial implementation barrier. In addition, sharing of the costs by all stakeholders who benefit from smaller subsidence rates will also enhance the feasibility of the implementation.

\subsection{Considering soil heterogeneity}

The results show that the effects of pressurized drains on the four sites in the research area are similar, but not identical. The differences can be attributed to the heterogeneity of the peat soils, with marked differences between and within one parcel. Although the drained and control parcels were chosen carefully, reflecting very similar soil characteristics, ground surface levels, and agricultural management, differences between them might still exist. Unfortunately, due to the conditions imposed by real-world farm management, it was not possible to install more groundwater observation wells, or to drain only half of the parcels, which would make the parcels better comparable. Therefore, although we believe we demonstrated the effectiveness of the technique, more research is needed to enhance the predictability of the magnitude of the effects and the generalizability of the results to other locations.

\subsection{Propagating long-term monitoring}

Soil subsidence in peatlands is a slow process. An empirical analysis of Dutch soil subsidence data suggests that a longterm average soil subsidence of $7 \mathrm{~mm} \mathrm{yr}^{-1}$ can be expected in polder Spengen (Van den Akker et al., 2008). To measure a change in such small rates accurately, long-term monitoring is needed. Although we believe that our research shows that pressurized drainage can indeed slow down soil subsidence, the conclusions based on 2.5 years of monitoring must be seen as preliminary.

\section{Conclusions}

Our research showed that pressurized drainage can be effectively implemented in real-world situations, but the implementation costs of EUR 4700-6500 might be a barrier to large-scale implementation. We were able to manipulate groundwater tables effectively by pressurized drainage. During the extreme dry summer of 2018 , we were able to raise groundwater tables by $50-90 \mathrm{~cm}$. The magnitude of the raise varied because of the heterogeneity of the soil, in particular the amount of clay in the topsoil seemed to raise the magnitude. Therefore, we must be careful to generalize the results to other locations. Although the relation between higher groundwater tables and less soil subsidence was clearly visible during summer 2018, the monitoring period is too short to determine a long-term effect on soil subsidence just yet. With regard to the water demand of pressurized drainage, the preliminary results seem to indicate that this resembles the amount of evaporation.

Data availability. All data used in this study are available on the HDSR website https://www.hdsr.nl/beleid-plannen/veenweide/ bedrijvenproef/ (Hoogheemraadschap de Stichtse Rijnlanden, 2020).

Author contributions. AvS initiated the project for HDSR, JH and AvS designed the method, JH, AS and HAvH conducted the analysis. $\mathrm{JH}$ and $\mathrm{HAvH}$ contributed to the writing of the paper.

Competing interests. The authors declare that they have no conflict of interest.

Special issue statement. This article is part of the special issue "TISOLS: the Tenth International Symposium On Land Subsidence - living with subsidence". It is a result of the Tenth International Symposium on Land Subsidence, Delft, the Netherlands, 17-21 May 2021.

Acknowledgements. We greatly thank the farmers that contributed in this project for their support and collaboration. We thank Esther Stouthamer for her review.

\section{References}

Berendsen, H. J. A. and Stouthamer, E.: Palaeogeographic development of the Rhine-Meuse delta, The Netherlands, Koninklijke van Gorcum - Assen, 2001.

Hoogheemraadschap de Stichtse Rijnlanden: Bedrijvenproef Spengen Sturen met grondwater - HDSR, HDSR, available at: https: //www.hdsr.nl/beleid-plannen/veenweide/bedrijvenproef/, 2020.

Schothorst, C. J.: Subsidence of low moor peat soils in the western Netherlands, Geoderma, 17, 265-291, https://doi.org/10.1016/0016-7061(77)90089-1, 1977.

Van Asselen, S., Erkens, G., Stouthamer, E., Woolderink, H. A. G., Geeraert, R. E. E., and Hefting, M. M.: The relative contribution of peat compaction and oxidation to subsidence in built-up areas in the Rhine-Meuse delta, The Netherlands, Sci. Total Environ., 636, 177-191, https://doi.org/10.1016/j.scitotenv.2018.04.141, 2018. 
Van den Akker, J. J. H., Kuikman, P. J., de Vries, F., Hoving, I., Pleijter, M., Hendriks, R. F. A., Wolleswinkel, R. J., Simões, R. T. L., and Kwakernaak, C.: Emission of $\mathrm{CO}_{2}$ from Agricultural peat soils in the Netherlands and ways to limit this emission, in: Proceedings of the 13th International Peat Congress After Wise Use - The Future of Peatlands, Vol. 1 Oral Presentations, edited by: Farrell, C. and Feehan, J., Tullamore, Ireland, 8-13 June 2008, International Peat Society, Jyväskylä, pp. 645-648, 2008.
Van Hardeveld, H. A., Driessen, P. P. J., Schot, P. P., and Wassen, M. J.: Supporting collaborative policy processes with a multicriteria discussion of costs and benefits: The case of soil subsidence in Dutch peatlands, Land Use Policy, 77, 425-436, https://doi.org/10.1016/j.landusepol.2018.06.002, 2018. 